\title{
Evaluation of dairy sheep lambs supplemented with crude glycerin conveyed in water during pregnancy and lactation
}

\section{Glicerina bruta veiculada à água como suplemento para gestação e período de transição em ovelhas}

\author{
Hemilly Cristina Menezes Sá ${ }^{*}$; Iran Borges ${ }^{2}$; Gilberto de Lima Macedo Junior ${ }^{3}$; \\ Felipe Santiago Santos ${ }^{4}$; Luigi Francis Lima Cavalcanti ${ }^{5}$; Flávio Augusto Pereira \\ Alvarenga $^{6}$; Tássia Ludmila Teles Martins ${ }^{6}$; Joana Palhares Campolina ${ }^{4}$
}

\begin{abstract}
The aim of this study was to evaluate the influence of crude glycerin (CG) suplementation in sheep diets during pregnancy and transition period. Twenty-four Lacaune $\mathrm{x}$ East Friesian genotypes sheep were randomly assigned to four treatments. Diet was composed of roughage: tifton hay, and standard concentrate for the categories, being these similar among the treatments, whereas the CG differed for the supplements in (zero, 1,5, 3,0 and 4,5\% of dry matter) being It added to the animals' drinking water. The sheep received supplementation during all pregnancy and lactation. Dry matter intake during gestation was reduced with the higher supplementation of CG in the animals' drinking water, presenting a linear decreasing response and remaining until delivery. Throughout lactation, the variable presented a linear behavior with the supplementation of $\mathrm{CG}$ on the eighteenth day of this phase, after a quadratic behavior was observed until the end of the evaluated period. The $\beta$-hydroxybutyrate and non-esterified fatty acids levels were not influenced by CG supplementation throughout the gestation period. CG suplementation conveyed in water did not affect negatively milk production and composition.
\end{abstract}

Key words: $\beta$-hydroxybutyrate. Byproducts. Glycerol. Sheep.

\section{Resumo}

Objetivou-se avaliar a influência da suplementação com glicerina bruta (GB) em dietas para ovelhas durante a gestação e período de transição. Foram avaliadas 24 ovelhas com genótipo Lacaune x East Friesian distribuídas de forma inteiramente ao acaso em quatro tratamentos. A dieta foi composta de volumoso: feno de tifton e concentrado padrão para as categorias, sendo estes semelhantes entre os tratamentos já a GB diferenciava quanto às suplementações em (zero; 1,5; 3,0 e 4,5\% da MS) sendo a mesma adicionada à água de beber dos animais. As ovelhas receberam suplementação ao longo da gestação e lactação. O consumo de matéria seca na gestação foi reduzido com a maior suplementação de

${ }^{1}$ Prof $^{a}$, Departamento de Engenharia Agronômica, Universidade Federal Sergipe, UFS, São Cristóvão, SE, Brasil. E-mail: hemilly. mg@hotmail.com

2 Prof., Universidade Federal de Minas Gerais, UFMG, Escola de Veterinária, Belo Horizonte, MG, Brasil. E-mail: iran@vet. ufmg.br

3 Prof., Universidade Federal de Uberlândia, UFU, Uberlândia, MG, Brasil. E-mail: gilbertomacedojr@gmail.com

4 Mestres, UFMG, Belo Horizonte, MG, Brasil. E-mail: felipessantos@outlook.com; joana.campolina@yahoo.com.br

5 Dr. em Zootecnia, Área de Concentração Alimentação e Nutrição Animal, Escola de Veterinária, UFMG, RHAE/SEVA Engenharia, Projeto Intergado, Contagem, MG, Brasil. E-mail: luigicavalcanti22@gmail.com

6 Discentes, Programa de Pós-Graduação em Zootecnia, Área de Concentração Alimentação e Nutrição Animal, Escola de Veterinária, UFMG, Belo Horizonte, MG, Brasil. E-mail: flaviozooalvarenga@yahoo.com.br; talutema@yahoo.com.br

* Author for correspondence

Received: Oct. 20, 2016 Approved: May 29, 2017 
GB na água de beber dos animais, apresentando resposta linear decrescente e mantendo-se até o parto. Ao longo da lactação, a variável apresentou comportamento linear decrescente com a suplementação da GB no décimo oitavo dia desta fase, posteriormente apresentando um comportamento quadrático até o fim do período avaliado. $O$ teor de $\beta$-hidroxibutirato e ácidos graxos não esterificados não sofreram influência da suplementação com GB ao longo de toda a gestação. A suplementação com GB veiculada à água não afetou negativamente a produção e composição do leite.

Palavras-chave: $\beta$-hidroxibutirato. Glicerol. Ovinos. Subprodutos.

\section{Introduction}

Global demand for biofuels is increasing to meet the world's energy needs, resulting in a surplus production of crude glycerin (CG). CG is the result of a vegetable oil or animal fat transesterification reaction in contact with methanol or ethanol, in the presence of a basic or biological acid catalyst, generating biodiesel and $\mathrm{CG}$ as a co-product (THOMPSON; HE, 2006).

$\mathrm{CG}$ is recognized as safe for use in animal diets (FDA, 2006). In ruminants, it can be converted to volatile fatty acids, particularly propionate and butyrate instead of acetate, or it can be directly absorbed by the digestive system, acting as a precursor for gluconeogenesis in the liver (RÉMOND et al., 1993; KREHBIEL, 2008). Studies have demonstrated its energetic potential in ruminant diets (FISHER et al., 1971; RÉMOND et al., 1993; KHALILI et al., 1997; DEFRAIN et al., 2004; CHUNG et al., 2007; OSBORNE et al., 2009). However, surveys conducted during the gestational phase and transition period in ewes are still scarce, justifying researches that determines its inclusion limit as well as its use evaluation as a supplementary ingredient for the prevention of metabolic disorders.

The increase in energy demand at the end of gestation coincides with the reduction of food intake as well as the fetus rapid growth (FORBES, 2007). For energy maintenance, reserves mobilization occurs in face of this growing demand (MERCK, 2008). However, this negative energy balance and the increased fat deposits mobilization may overcome the metabolizing capacity of the liver and result in hepatic lipidosis with consequent liver injury (GONZÁLEZ; SILVA, 2006). In view of this scenario, $C G$ inserts itself as an energetic supplementation alternative to the end of gestation and the beginning of lactation in sheep. It can be diluted and offered in water as a strategy to reduce dry matter consumption and occupy less physical space. The aim of this study was to evaluate the CG supplementation conveyed in water for sheep, and to determine its effects on intake, blood parameters during gestation and milk production and composition during the transition period.

\section{Material and Methods}

Twenty-four Lacaune $x$ East Friesian genotype sheep, between three and four years old, with mean weight of $66.14 \pm 6.23$ kilos, housed in individualized stalls, were used. They were followed throughout the gestational period and during the first six weeks of lactation. The use of these animals is in accordance with a protocol approved by the Committee of Ethics in Animal Experimentation (CEUA, protocol 056/11).

The ewes were distributed in a completely randomized design, being allocated in four treatments that differed in crude glycerin supplementation levels. Diets were formulated meeting nutritional requirements for each category (gestation or lactation), as recommended by the NRC (2007) Table 1. Feeding was divided into two equal meals at 0800 and 1600 . It is worth mentioning that CG inclusions were inserted into the drinking water provided to the animals, as dietary supplementation, being added in the inclusions (zero, 1.5\%, 3.0\% and $4.5 \%$ ) according to the dry matter intake and water 
consumption. GB established amount for each animal was weighted, diluted in water, and made up a solution (glycerin + water) in a total of $10 \mathrm{~kg}$ for each animal. The CG supply and diet offer were adjusted every four days. Glycerin bromatological composition is shown in Table 2.

Roughage and concentrated supplies were weighed daily, as well as leftovers of the experimental diet, to determine the individual consumption. Water leftover as also weighted for later calculation of the CG surplus. All animals received the experimental diet according to the consumption of the previous day, in order to maintain the percentage of the diet leftovers around ten percent of the one offered.

Table 1. Percentage and chemical composition of the rations offered to the ewes during pregnancy and lactation.

\begin{tabular}{lccc}
\hline Ingredient $^{*}(\%)$ & $0-120$ days pregnancy & $120-145$ days pregnancy & Lactation \\
\hline Tifton hay & 60,27 & 52,39 & 50,33 \\
Corn meal & 36,08 & 41,02 & 31,51 \\
Soybean meal & 2,12 & 5,00 & 16,22 \\
Sheep salt & 1,00 & 1,00 & 1,00 \\
Common salt & 0,50 & 0,50 & 0,50 \\
Limestone & 0,017 & 0,182 & 0,346 \\
Dicalcium Phosphate & 0,005 & 0,005 & 0,095 \\
Nutrient $\left.{ }^{*} \%\right)$ & & & \\
Dry matter & 89,02 & 89,04 & 89,56 \\
Crude protein & 10,00 & 14,24 & 15,57 \\
NDF & 47,56 & 42,68 & 42,00 \\
ADF & 23,35 & 21,00 & 21,00 \\
Calcium & 0,31 & 0,48 & 0,43 \\
Phosphorus & 0,24 & 0,29 & 0,37 \\
TDN & 67,43 & 69,63 & 69,53 \\
\hline
\end{tabular}

*Values expressed based on dry matter. NDF $=$ neutral detergent fiber, $\mathrm{ADF}=$ acid detergent fiber, $\mathrm{TDN}=$ total digestible nutrients. Assurance levels (nutrient kg-1): calcium-150 g; sulfur-12 g; phosphorus -65 g; magnesium-6 $\mathrm{mg}$; sodium-107 g; copper-100 mg; cobalt-175 mg; iron-1000 mg; maximum Fluor-650 mg; iodine-175 mg; manganese-1440 mg; selenium-27 mg and zinc-6000 mg.

In order to follow up the metabolic profile, blood samples were collected at 70, 85, 100, 115, 125, 135, 145 days of gestation. Blood was collected by jugular venipuncture with the aid of vacuntainer and tubes without anticoagulant for metabolic profile analysis. Samples were collected in the morning, before the first feeding. Then, blood was centrifuged at 5000 RPM for five minutes, and the serum separated into aliquots, stored in microtubes (eppendorf $($ ) and kept in a freezer at $-5^{\circ} \mathrm{C}$ for further laboratory processing. Biochemical components of energy metabolism were $\beta$-hydroxybutyrate and nonesterified fatty acids (NEFA).

Post-partum ewes were followed up for six weeks in order to evaluate $\mathrm{CG}$ performance as an energy supplement in the transition period. Milk production was measured from the 10th day of lactation. To perform the milking, the sheep were separated from their lambs for a period of 12 hours in order to allow milk to accumulate in their mammary glands. For this procedure, the animals were placed on a platform and restrained. Milking was performed 
Table 2. Chemical composition and energy content of the crude glycerin.

\begin{tabular}{cc}
\hline Nutrient & Nutrient $\%^{*}$ \\
\hline Dry matter & 85,40 \\
Crude protein & 0,06 \\
Glycerol & 80,70 \\
Ether extract & 13,41 \\
Mineral matter & 5,71 \\
NDF & - \\
ADF & - \\
TCH & 75,00 \\
NFC & 75,00 \\
Density $(\mathrm{g} / \mathrm{mL})$ & 1,20 \\
Energy $(\mathrm{kcal} / \mathrm{kg})$ & 3954,00 \\
\hline
\end{tabular}

*Values expressed based on dry matter. $\mathrm{NDF}=$ neutral detergent fiber, $\mathrm{ADF}=$ acid detergent fiber, $\mathrm{TCH}=$ total carbohydrates, $\mathrm{NFC}=$ non-fiber carbohydrates.

daily, in a mechanical system, in the afternoon. For the removal of all the milk contents present in the mammary gland cystern, $0.5 \mathrm{~mL}$ oxytocin was intramuscularly applied at a concentration of 10 IU mL-1. Daily milk production was individually weighed on a $10 \mathrm{~g}$ precision weighing digital scale.

A $40 \mathrm{~mL}$ aliquot of whole milking milk was collected weekly. Bronopol preservative was added, and the sample was cooled and sent to the Laboratory of milk quality (LabUFMG) to evaluate milk composition. Milk composition analyzes were performed on Bentley $2000 \AA$ equipment, coupled with Somacount $300 \AA$ (Bentley Instruments Inc. 4004, Peavey Road Chaska, MN 55318 U), according to IDF Whole Milk (2000). Daily milk production and fat and protein percentage obtained in the milk composition analyzes were used to calculate the milk production corrected to $6.5 \%$ fat and $5.8 \%$ protein $(\mathrm{FCM})$, based on the following equations developed by Pulina et al. (1989):

$$
\begin{aligned}
& 6.5 \mathrm{FMY}=\mathrm{MY}(0.37+(0.097 \times \mathrm{F})) \\
& \mathrm{CMY}=6.5 \mathrm{FMY}(0.25+(0.05 \times \mathrm{F})+(0.035 \times \mathrm{P})
\end{aligned}
$$

Where: $6.5 \mathrm{FMY}=6.5$ percent fat corrected milk (kg); MY = milk yield, $\mathrm{kg} ; \mathrm{F}=$ milk fat concentration
(\%); $\mathrm{CMY}=$ corrected milk, $\mathrm{kg} ; \mathrm{P}=$ milk protein concentration (\%). Milk yield of each milking was summed to the milk consumed by lambs, and it was estimated by weigh-suckle-weigh technique, were lambs were weighed prior to suckling the ewe, allowed to suckle, and weighed again immediately following suckling. The difference between pre and post suckling weights was considered milk consumption by lambs (BENSON et al., 1999). Those results were considered the total and daily quantity of milk produced by ewes.

The study was carried out to verify if the assumptions of normal distribution, additivity and homoscedasticity of the data were met. The statistical model used for data analysis is as follows:

$$
Y i j k=\mu+X i+\sigma j(i)+\tau k+\varepsilon i j k
$$

on what:

Yijk = observed characteristic value;

$\mu=$ general mean;

$\mathrm{Xi}=$ diet relative effect (crude glycerin contents);

$\Sigma \mathrm{j}$ (i) = days before birth and lactation relative effect, 
$\mathrm{Tk}=$ effect of the interaction between diet $\mathrm{i}$ and days $\mathrm{j}$;

$\varepsilon i j \mathrm{k}=$ random error, associated with each observation Yijk.

The quantitative variables were analyzed by means of adjustment of mixed linear models in which the parameters were estimated by restricted maximum likelihood, where the effects of supplementation with $\mathrm{CG}$ and phases (days in relation to lamb birth or stages) were allocated as fixed effects, and the sheep where allocated as randomly assigned to the model.

The need to include functions to model any heteroscedasticity between glycerin levels for each variable was evaluated using the fitted Akaike's criterion (AIC). Autoregressive correlation structures were also used to detect error dependency between phases.

Statistical analyses were conducted in $\mathrm{R}$ ( $\mathrm{R}$ CORE TEAM, 2014). Mixed models were fitted using the nlme package (PINHEIRO et al., 2013), whereas the graphs were generated using the ggplot2 package (WICKHAM, 2009).

\section{Results and Discussion}

During the final trimester of pregnancy ewes presented a decrease in dry matter intake (DMI) due to physiological changes related to this period. Therefore that reduction in DMI was enhanced by CG supplementation and this parameter decreased linearly until calving (Figure 1).

Figure 1. Dry matter intake $\left(\mathrm{g} \mathrm{k}^{-1}\right)$ due to $\mathrm{CG}$ supplementation and days related to pregnancy and lactation.

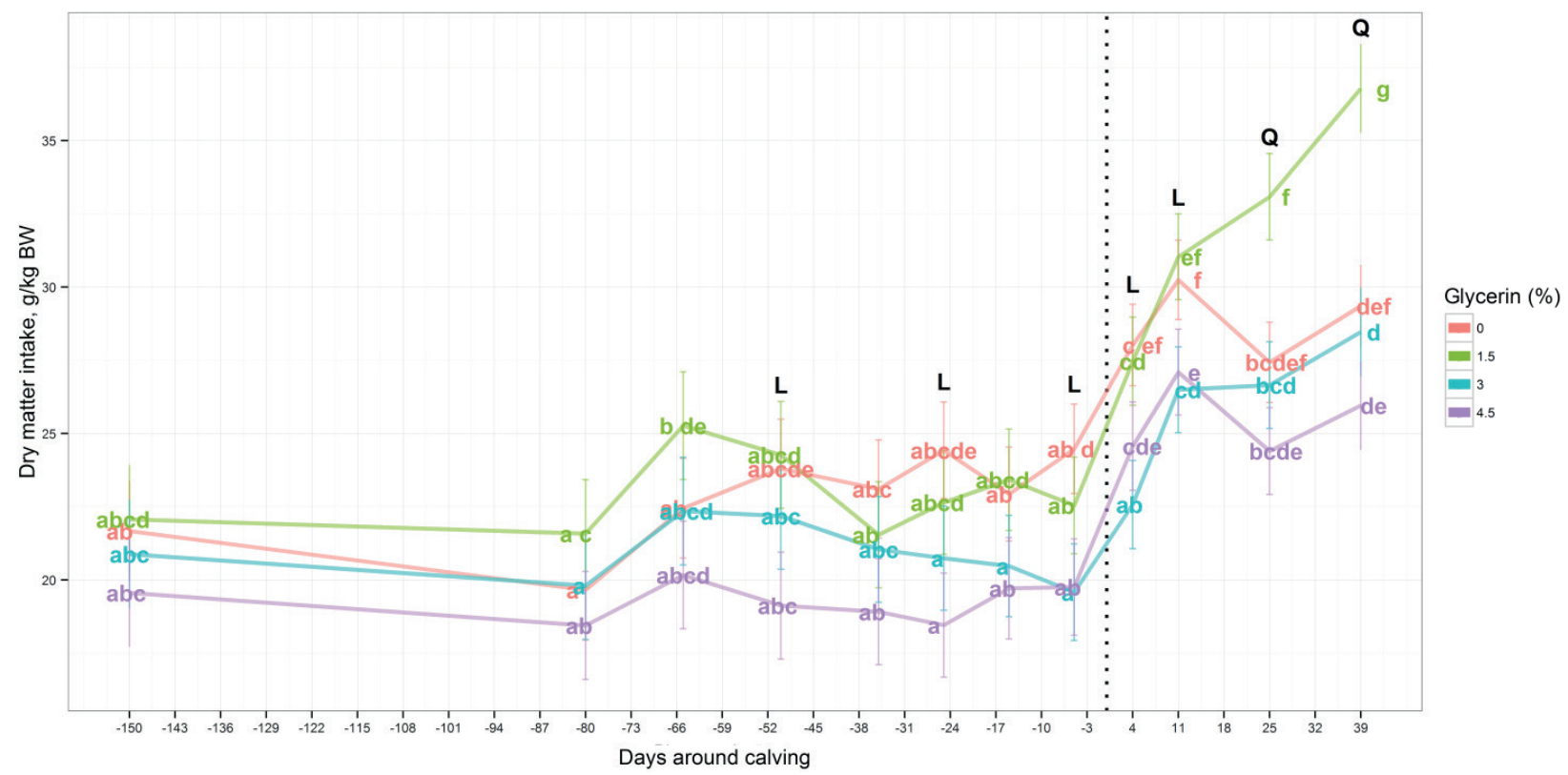

Different lowercase letters within each treatment indicates significant difference between days around calving $(\mathrm{P}<0.05)$. L and $\mathrm{Q}$ indicate linear or quadratic effect of glycerin inclusion within each day around calving $(\mathrm{P}<0.05)$. 
Throughout lactation we observed an increase in DMI, however its behavior was linearly decreased with the CG supplementation on the first 18 days of that period, subsequently presented a quadratic trend until the end of lactation.

DMI for the CG supplemented ewes at 1.5\% was higher than other treatments during pregnancy and lactation periods. Mertens (1997, 1994) considered that DMI could be regulated by three different mechanisms: physical, physiological and psychogenic. In this study, DMI behavior can be explained by the physiological mechanisms, in which intake is a reciprocal function of feed characteristics, such as fill effect and energy content to meet the energy requirements of the animal.

The CG acts as precursor for energy sources (DONKIN, 2008). We suggest that performance and physiological state requirements were met by the chemostatic regulation factors. Thus, the reduction on DMI observed can be explained by the high CG content $(\%)$ in supplemented water provided to the ewes.

Ruminants are capable to control their energy intake similarly to non-ruminant animals, as long as the energy density of their diets is high enough to avoid interference by physical restrictions (FORBES, 1993). We highlighted that diets of current study were similar and differed only by CG content (\%) in supplemented water provided to the ewes, then dams were capable to alter their intake based on their energy requirements. Osborne et al. (2009) noted a reduction in DMI at the week before calving for cows supplemented with CG $(99,7 \%$ of glycerol) in drinking water during transition period. Because animals eat primarily to meet their energy requirements, if an animal is in positive energy balance, providing additional metabolizable energy would theoretically decrease feed intake.

Research in which the CG was used to replace corn grain and not as a supplement showed no effect on DMI for transition cows (KHALILI et al., 1997; SCHRÖDER; SÜDEKUM, 1999; DEFRAIN et al., 2004). Donkin et al. (2009) suggested the purity of glycerol as a determining factor for adverse effects of glycerol, particularly in the case of reduced feed intake. Impurities in biodiesel derived glycerin may adversely affect intake. The value of the latter will be reduced if substantial contaminants are present or if diluents including water, fat, methanol, and minerals are present (THOMPSON; HE, 2006). The present study was conducted with $80,7 \%$ of glycerol.

In Brazil, the Agriculture, Livestock and Food Supply Ministry - MAPA, considered CG at 12\% (DM basis) to be acceptable as animal feed (MAPA, 2010). This recommendation is based on the lack of experiments which can prove the possibility of using $\mathrm{CG}$ at higher levels of inclusion.

Blood parameters were evaluated and we demonstrated that there were no differences in the concentration of BHBA throughout pregnancy (Figure 2). BHBA concentrations in serum were within normal range (zero to $0,7 \mathrm{mmol} \mathrm{L}^{-1}$ ) as cited by Kaneko et al. (2008). 
Figure 2. $\beta$-hidroxibutirato blood levels $\left(\mathrm{mmol} \mathrm{L}^{-1}\right)$ due to $\mathrm{CG}$ supplementation and days related to pregnancy.

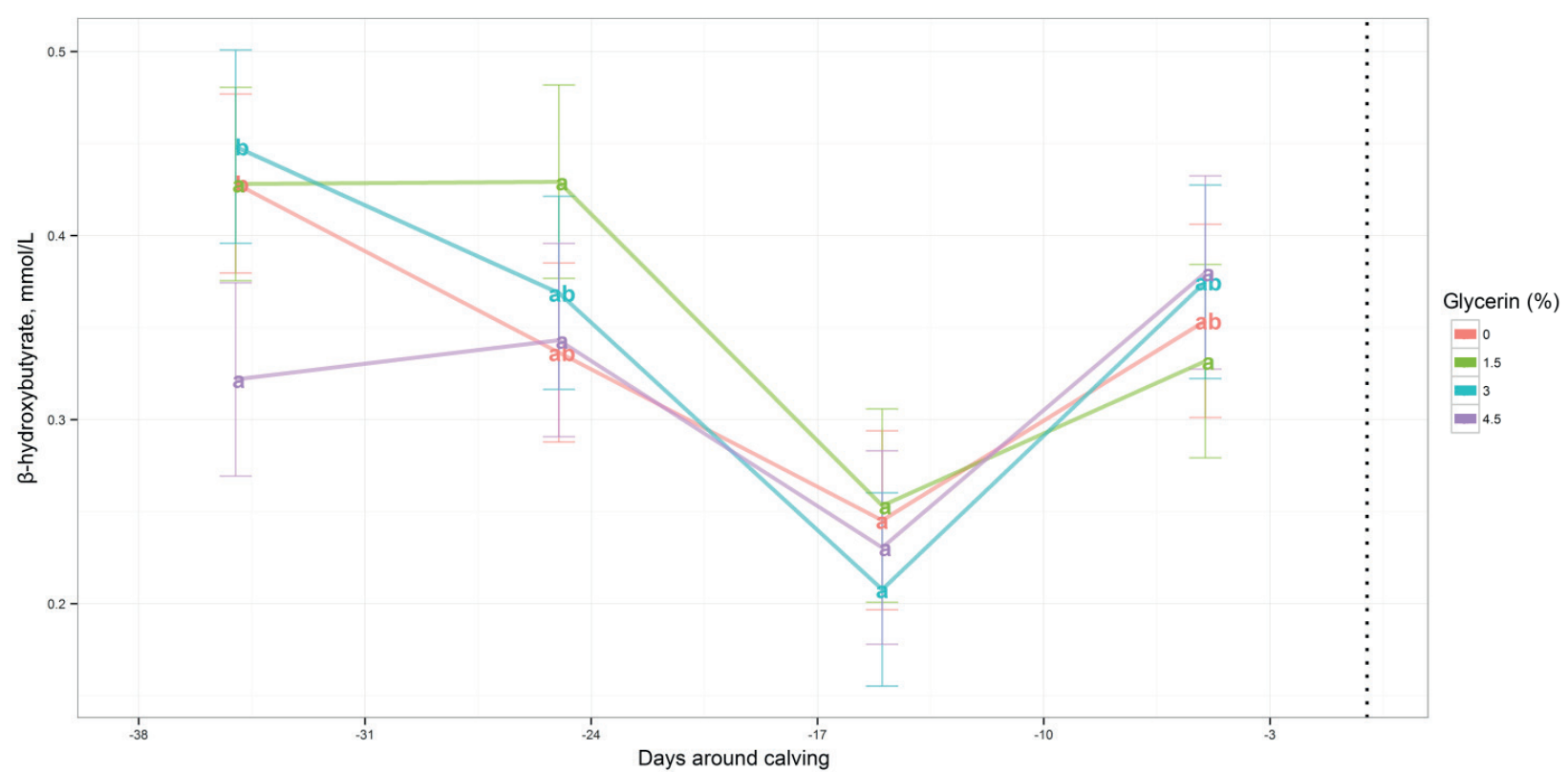

Different lowercase letters within each treatment indicates significant difference between days around calving $(\mathrm{P}<0.05)$. $\mathrm{L}$ and $\mathrm{Q}$ indicate linear or quadratic effect of glycerin inclusion within each day around calving $(\mathrm{P}<0.05)$.

There were no differences $(\mathrm{P}>0,05)$ in the concentration of NEFA, which remained relatively constant. These concentrations were altered only throughout pregnancy for the CG supplemented at $3.0 \%$, however these values are within normal range $\left(<0,4 \mathrm{mmol} \mathrm{L}^{-1}\right)$ as referred by Kaneko et al. (2008).
The concentration of NEFA presented in the current study demonstrate that fat mobilization is a common feature in dairy animals and reflects increased reliance on adipose reserves to support energy requirements throughout the experimental period and treatments (Figure 3). 
Figure 3. Non esterified fatty acids $\left(\mathrm{mmol} \mathrm{L}^{-1}\right)$ due to $\mathrm{CG}$ supplementation and days related to pregnancy.

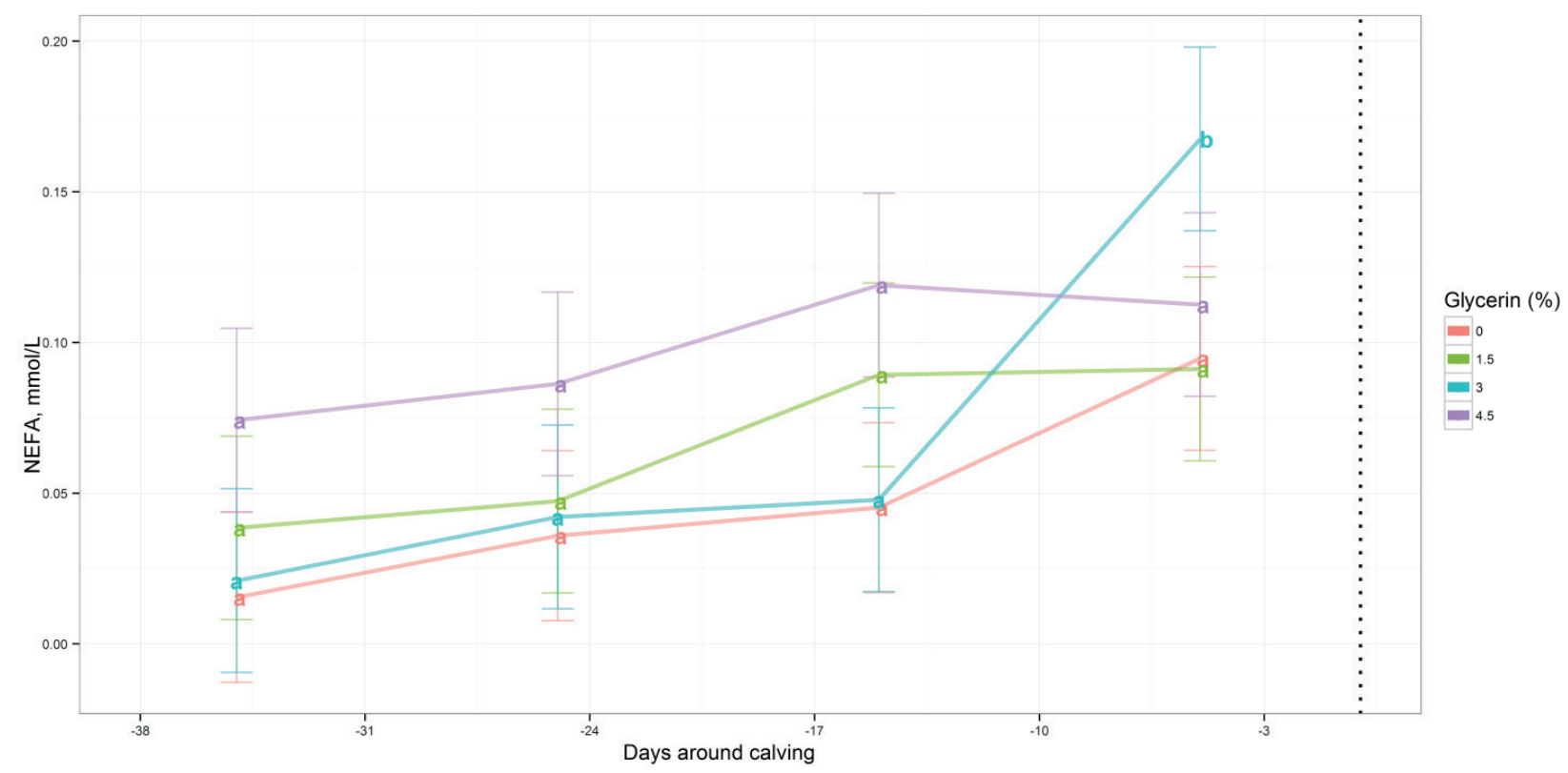

Different lowercase letters within each treatment indicates significant difference between days around calving $(\mathrm{P}<0.05)$. $\mathrm{L}$ and $\mathrm{Q}$ indicate linear or quadratic effect of glycerin inclusion within each day around calving $(\mathrm{P}<0.05)$.

These data suggest CG supplemented in the drinking water to be a viable energetic feed, although addition of CG has been shown to reduce DMI, this supplementation had no effect on fat mobilization, and consequently, NEFA concentrations.

There were no effects of CG supplementation on milk yield during the evaluated period (Figure 4). Milk composition was not affected by CG addition in drinking water during lactation period.

Although we reported that CG supplementation decreased DMI of ewes, those animals were able to avoid changes in body condition score. This result is related to the normal concentrations of BHBA and NEFA and reflects improved energetic efficiency with CG feeding.

We highlighted that CG supplementation reduced
DMI, however did not affect milk production and composition. Although during pregnancy period, there were no differences in the body condition score change, parameter was not evaluated throughout the lactation period. We suggest further evaluation during lactation period in order to determine which level CG can be included in rations as a supplement for lactating dairy ewes. Beyond those opportunities to use CG as an energy source for livestock, it can also represent many benefits to environment.

Few studies demonstrate the potential of $\mathrm{CG}$ to increase rumen propionate (expressed as percentages of total VFA) at the expense of acetate (SCHRÖDER; SÜDEKUM, 1999; DEFRAIN et al., 2004; WANG et al., 2009). Lee et al. (2011) indicated that addition of glycerol reduced $\mathrm{CH}_{4}$ production in vitro. 
Figure 4. Total milk production corrected to $6.5 \%$ fat and $5.8 \%$ protein (FCM) due to $\mathrm{CG}$ supplementation and days related to pregnancy.

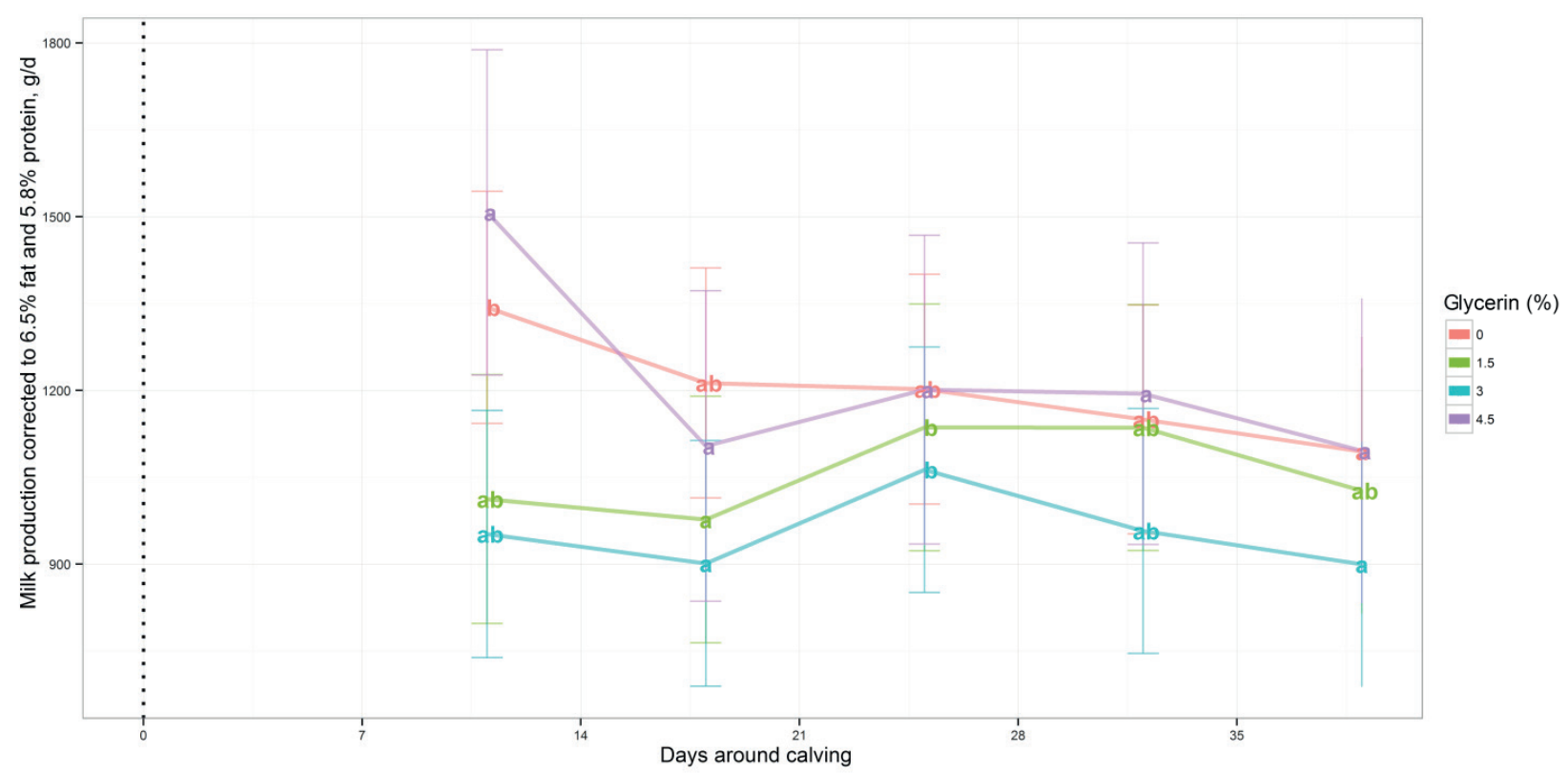

Different lowercase letters within each treatment indicates significant difference between days around calving $(\mathrm{P}<0.05)$. L and $\mathrm{Q}$ indicate linear or quadratic effect of glycerin inclusion within each day around calving $(\mathrm{P}<0.05)$.

\section{Conclusion}

Crude glycerin supplementation in drinking water had not effect on milk production and composition, and blood parameters of dairy ewes.

\section{References}

BENSON, M. E.; HENRY, M. J.; CARDELINO, R. A. Comparison of weigh-suckle-weigh and machine milking techniques for measuring milk production of ewes. Journal of Animal Science, Champaign, v. 77, n. 9, p. 2330-2335, 1999.

CHUNG, Y. H.; RICO, D. E.; MARTINEZ, C. M.; CASSIDY, T. W.; NOIROT, N.; AMES, A.; VARGA, G. A. Effects of feeding dry glycerin to early postpartum Holstein dairy cows on lactational performance and metabolic profiles. Journal Dairy Science, Champaign, v. 90, n. 12, p. 5682-5691, 2007.

DEFRAIN, J. M.; HIPPEN, A. R.; KALSCHEUR, K. F.; JARDON, P. W. Feeding glycerol to transition dairy cows: effects on blood metabolites and lactation performance. Journal Dairy Science, Champaign, v. 87, n. 12, p. 4195-4206, 2004.
DONKIN, S. S. Glycerol from biodíesel production: the new corn for dairy cattle. Revista Brasileira de Zootecnia, Viçosa, MG, v. 37, p. 280-286, 2008. Suplemento Especial.

DONKIN, S. S.; KOSER, S. L.; WHITE, H. M. Feeding value of glycerol as a replacement for corn grain in rations fed to lactating dairy cow. Journal of Dairy Science, Champaign, v. 92, n. 10, p. 5111-5119, 2009.

FISHER, L. J.; ERFLE, J. D.; SAUER, F. D. Preliminary evaluation of the addition of glucogenic materials to the rations of lactating cows. Canadian Journal of Animal Science, Champaign, v. 51, n. 3, p. 721-727, 1971.

FOOD AND DRUG ADMINISTRATION - FDA. Code of Federal Regulations. 21 CFR 582. 1320, Title 21, v. 6, [s.1.]: FDA, 2006. Available at: $<$ http://edocket.access. gpo.gov/cfr_2002/aprqtr/21cfr582.1320.htm>. Accessed at: 06 out 2016

FORBES, J. M. Voluntary feed intake. In: FORBES, J. M.; FRANCE, J. (Ed.). Quantitative aspects of ruminant digestion and metabolism. Cambridge: University Press, 1993. p. 479-494.

FORBES, J.M. A personal view of how ruminant animals control their intake and choice of food: minimal total 
discomfort. Nutrition Research Reviews, Cambridge, v. 20, n. 1 p. 132-146, 2007.

GONZÁLEZ, F. H. D.; SILVA, S. C. Bioquímica clínica de glicídios. In: GONZÁLEZ, F. H. D.; SILVA, S. C.; CERON, J. J. Introdução a bioquímica clínica veterinária. $2^{\text {th }}$ ed. Porto Alegre: Editora da Universidade Federal do Rio Grande do Sul, 2006. p. 153-207.

KANEKO, J. J. Clinical biochemistry of domestic animals. San Diego: Academic Press, 2008. 932 p.

KHALILI, H.; VARVIKKO, T.; TOIVONEN, V.; HISSA, K.; SUVITIE, M. The effects of added glycerol or unprotected free fatty acids or a combination of the two on silage intake, milk production, rumen fermentation and diet digestibility in cows given grass silage based diets. Agricultural and Food Science, Helsinki, v. 6, n. 1, p. 349-362, 1997.

KREHBIEL, C. R. Ruminal and physiological metabolism of glycerin. Journal of Dairy Science, Champaign, v. 86, n. 1, p. 392-393, 2008.

LEE, S.; LEE, S.; YOUNG-BAE, C.; KEM, D.; LEE, S.; KIM, C.; SEO, S. Glycerol as a feed supplement for ruminants: in vitro fermentation characteristics and methane production. Animal Feed Science and Technology, Amsterdam, v. 166-167, n. 1, p. 269- 274, 2011.

MERCK Veterinary Manual. Pregnancy toxemia in ewes. $9^{\text {th }}$ ed. Kenilworth: Merck \& Co., Inc. Whitehouse Station, 2008.

MERTENS, D.R. Regulation of forage intake. In: FAHEY JUNIOR, G. C.; COLLINS, M.; MERTENS, D. R.; MOSER, L. E. Forage quality, evaluation, and utilization. Madison: American Society of Agronomy, Crop Science Society of America, and Soil Science Society of America, p. 450- 493, 1994.

MERTENS, D. R. Creating a system for meeting the fibre requirements of dairy cows. Journal of Dairy Science, Champaign, v. 80, n. 7, p. 1463-1481, 1997.

MINISTÉRIO DA AGRICULTURA PECUÁRIA E ABASTECIMENTO - MAPA. GENPA 80 GRANOL. Ingrediente vegetal, Código SIF: RS-15127, 2010. Available at: http://www.agricultura.gov.br/assuntos / insumos-agropecuarios/ animal/legislacao/instrucaonormativa-no-42-de-16-de-dezembro-de-2010.pdf/ view>. Accessed at: 20 Out. 2016.

NATIONAL RESEARCH COUCIL - NRC. Nutrient requeriments of small ruminants. $7^{\text {th }}$ ed. Washington: National Academic Press, 2007. 408 p.
OSBORNE, V. R.; ODONGO, N. E.; CANT, J. P.; SWANSON, K. C.; MCBRIDE, B. W. Effects of supplementing glycerol and soybean oil in drinking water on feed and water intake, energy balance, and production performance of periparturient dairy cows. Journal of Dairy Science, Champaign, v. 92, n. 2, p. 698-707, 2009.

PINHEIRO, J.; BATES, D.; DEBROY, S.; SARKAR, D. $R$ Development Core Team \& nlme: linear and nonlinear mixed effects models: R Package Version, 3.1- 110. Software. Foundation for Statistical Computing, Vienna, Austria, 2013. (Conjunto de programas. CD-ROM).

PULINA, G.; SERRA, A.; CANNAS, A. et al. Determinazione e stima del valore energetico di latte di pecore di razza Sarda. Atti della Società Italiana delle Scienze Veterinarie, Pisa, v. 43, n. 4, p. 1867-1870, 1989.

R CORE TEAM. R: A language and environment for statistical computing. Vienna: R Foundation for Statistical Computing, 2014. Available at: $<$ http://www.R-project. org/2014>. Accessed at: 20 out. 2016.

RÉMOND, B.; SOUDAY, E.; JOUANY, J. P. In vitro and in vivo fermentation of glycerol by rumen microbes. Animal Feed Science and Technology, Amsterdam, v. 41, n. 2, p. 121-132, 1993.

SCHRÖDER, A.; SÜDEKUM, K. H. Glycerol as a byproduct of biodiesel production in diets for ruminants. In: INTERNATIONAL RAPESEED CONGRESS, 10., 1999, Canberra. Proceeding... New Horizons for an Old Crop. Proceedings... Camberra: The Regional Institute, 1999. Paper n. 241.

THOMPSON, J. C.; HE, B. B. Characterization of crude glycerol from biodiesel production from multiple feedstocks. Applied Engineering in Agriculture, St Joseph, v. 22, n. 2, p. 261-265, 2006.

WANG, C.; LIU, Q.; YANG, W. Z.; DONG, K. H.; HUANG, Y. X.; GUO, G. Effects of glycerol on rumen fermentation, urinary excretation of purine derivatives and feed digestibility in steers. Livestock Science, Amsterdam, v. 121, n. 1, p. 15-20, 2009.

WHOLE MILK: determination of milk fat, protein and lactose content. Guidance for the operation of mid-infrared instruments. Bruxells: International IDF Standard, 141C, 2000. 12 p.

WICKHAM, H. ggplot2: elegant graphics for data analysis. Software.New York: Springer, 2009. (Conjunto de programas. CD-ROM). 